\title{
COVID-19 Pneumonia and Acute Kidney Injury: Delivery of Hemodialysis Therapy
}

\section{(iD) Zeki Kemeç ${ }^{1}$}

${ }^{1}$ M.D. Spec., Batman Education and Research Hospital Nephrology Clinic, Batman,Turkey.

\section{Ozz}

COVID-19 Pnömonisi ve Akut Böbrek Hasarı: Hemodiyaliz Tedavisi

Koronavirüs hastalığı 2019 (COVID-19), șiddetli akut solunum sendrom coronavirus 2 virüsünün (SARS-CoV-2) neden olduğu bulașıCı bir hastalıktır. COVID-19 hastalığına yakalanan hastalarda akut böbrek hasarı (ABH) ortaya çıkmaktadır. ABH hafif proteinüri, hematüri ve kreatininde hafif yükselme gibi tablolar ile kendini göstermektedir. Virüsün böbrek tropizmi ve multiorgan yetmezliği bu klinik tablolara zemin hazırlanmaktadır. Bu vaka raporunda, hipertansiyon (HT), diabetes mellitus (DM) ve geçirmiş tüberküloz anamnezi gibi komorbid durumları olan 69 yaşındaki bir bireyde, COVID-19 pnömonisi ile ilișkili ABH saptandı. Hipoksi, hipotansiyon ve anüri bulguları nedeniyle yoğun bakım ünitesinde izlendi. Üç seans hemodiyaliz (HD) uygulandı. Hasta tedaviye cevap verdi ve böbrekleri tamamen iyileşti.

Anahtar Kelimeler: Koronavirüs Hastalı̆̆ı 2019, Akut Böbrek Hasarı, Hemodiyaliz

\section{Abstract}

\section{COVID-19 Pneumonia and Acute Kidney Injury: Delivery of Hemodialysis Therapy}

Coronavirus disease 2019 (COVID-19) is a highly infective disease caused by the severe acute respiratory syndrome coronavirus 2 virus (SARS-CoV-2). It has been shown that the patients who contracted COVID-19 disease are exposed to kidney damage through acute kidney injury (AKI), mild proteinuria, hematuria or slight elevation in creatinine, probably as a result of kidney tropism of the virus and multiorgan failure. In this case report, a 69-year-old patient with a background of comorbid conditions, such as hypertension (HT), diabetes mellitus (DM) and a history of tuberculosis, had COVID-19 pneumonia associated with AKI. He was followed in intensive care units (ICU) due to the signs of hypoxia, hypotension and anuria. Hemodialysis (HD) was administrated in three sessions. The patient responded to the treatment, and his kidneys were fully recovered.

Keywords: Coronavirus Disease 2019, Acute Kidney Injury, Hemodialysis

Nasıl Atıf Yapmalı: Kemeç Z. COVID-19 Pneumonia and Acute Kidney Injury: Delivery of Hemodialysis Therapy. MKÜ Tıp Dergisi. 2021;12(44):236-240. https://doi. org/10.17944/mkutfd.894861 


\section{INTRODUCTION}

In late December 2019, it was reported that COVID-19 broke out in Wuhan City in the Hubei Province in China. It led to an epidemic in the territory of China and then rapidly spread into other countries around the world, where sporadic cases have been reported globally as a global health issue since then (1).

Kidney failure is a severe medical condition accompanied by a high prevalence of comorbid conditions, including diabetes mellitus (DM) and heart disease that heavily affect older adults (2). Acute kidney injury (AKI) is more commonly observed health problem among the patients with more severe disease, especially the patients being treated and recovered in the ICU, and it is recognized as a negative prognostic factor concerning the survival of the patients (3). The study conducted on 5,449 hospitalized patients demonstrated the incidence ratio of AKI as 36.6 , with $14.3 \%$ of these patients requiring dialysis, and this ratio was considerably higher for the patients admitted to the ICU. Besides, the mortality among the patients with AKI was higher in comparison with the patients that did not have AKI (35 and 16.3\%, respectively) (4).

Currently, no efficient antiviral drugs or appropriate vaccines have existed for the treatment of this disease. To treat symptomatic patients, supportive therapy is used, and most of the patients require mechanical ventilation and other intensive care services (ICU). We will try to present our case, to our knowledge, which is unique in the literature.

\section{CASE REPORT}

The 69-year-old male patient had diseases of HT and DM. He has a history of tuberculosis. He received the combination of medications metformin $1000 \mathrm{mg}$ /day and olmesartan 20 $\mathrm{mg} /$ day. He had no history of kidney disease and smoking. His wife contracted COVID-19 from the guests that had visited their house in Istanbul. His wife did not follow the self-isolation rule during her illness. Our patient initially had fatigue and muscle and joint pains accompanied by fever and sweating complaints. He mostly had a fever at nights. However, he did not take these complaints seriously. His complaints increased day by day. He started to have diarrhea three days ago. Difficulty in walking and feeling of syncopal affected his daily life adversely. The patient was hospitalized 15 days later with hypoxemia (blood oxygen saturation was $85 \%$ while breathing room air). There was a reduction in the discharge of urine. According to his physical examination results, his temperature was $37.3^{\circ} \mathrm{C}$, blood pressure was $90 / 50 \mathrm{~mm} \mathrm{Hg}$, heart rate was 112 beats/min, and heard rales in the bilateral lower lobes of his lungs. He had pretibial edema. In the laboratory analysis, lymphopenia, increase in inflammation parameters, uremia, metabolic acidosis, increased transaminases, increased muscle enzymes and impaired coagulation cascade were detected (Table 1). In his urine analysis, there was no hematuria and proteinuria (112 mg/day). In his 24hour urine, there was microalbuminuria $(120 \mathrm{mg} /$ day). His stool analysis was normal and required culture reproduction did not occur. In computed tomography of the thorax (thorax CT), bilateral multiple ground-glass opacities were observed, as shown in Figure 1 (Figures A-B-C). According to the reports published by the Chinese Guangdong Center for Disease Prevention and Control, positive results were obtained in throat swab samples twice after the SARS-CoV-2 nucleic acid tests. Given the epidemiologic characteristics and these findings, we diagnosed COVID-19 pneumonia.

Initially, he was admitted to the pandemic service. Oxygen support was provided by a nasal cannula for the treatment of the patient. His urine discharge was $300 \mathrm{cc} /$ day. The temporary HD catheter was inserted into the right jugular vein. The necessary isolation precautions were taken and the patient was hemodialyzed once. He stayed in the service for three days. He was transferred to the ICU due to unstable clinic condition, hypotension and oxygen support increase. He stayed in the ICU for eight days. He was treated with dual (nasal and oral) oxygen. His oxygen saturation did not fall below $85 \%$. His urine discharge did not exceed $400 \mathrm{cc} /$ day in the first five days of ICU. Due to hypotension, he needed inotropic (noradrenaline bitartrate) support. He had insistent metabolic acidosis. In addition, HD was administered for two sessions (two days between each session). He received a treatment protocol of favipiravir, methylprednisolone $40 \mathrm{mg} /$ day, paracetamol $1000 \mathrm{mg} /$ day, furosemide, enoxaparin sodium, pantoprazole $40 \mathrm{mg} /$ day and piperacillin sodium-tazobactam $(2000+250$ $\mathrm{mg} /$ day). He had no side effects from medications. When his general condition was stabilized (his tension rose to the normal limits, urine discharge was ensured, metabolic acidosis declined, oxygen support reduced), he was transferred to the service. He stayed in the service for eight days. On day 13, a declining trend was observed in the serum Cre, and after 21 days of treatment, negative results were obtained in throat swab samples twice after the SARS-CoV-2 nucleic acid test, fatigue and joint and muscle pains recovered, and inflammatory test results improved. The patient was discharged from the hospital. Two months later, his kidney values returned to normal. Four and half months later, his thorax CT findings were recovered Figure 1 (Figures D-E-F).

\section{DISCUSSION}

In his background, our old male patient had no diseases other than DM and HT. He had tuberculosis in the 20s. He was diagnosed with COVID-19 pneumonia by real-time reverse-transcriptase-polymerase chain reaction (rRT-PCR) and thorax CT (Typical changes were obtained from the computed tomography images in terms of the bilateral multiple ground-glass opacities), which is consistent with the reports previously published (5). 


\section{Table 1. Lahoratory values of the patient}

\begin{tabular}{|c|c|c|c|c|c|c|c|c|c|}
\hline Parameter & $1^{\text {st }}$ day & $2^{\text {nd d }}$ day & $8^{\text {th }}$ day & $10^{\text {th }}$ day & $13^{\text {rd d }}$ day & $17^{\text {th }}$ day & $27^{\text {th }}$ day & $45^{\text {th }}$ day & Referencerange \\
\hline Glucose & 122 & 66 & 80 & 89 & 83 & 126 & 92 & 101 & $80-140 \mathrm{mg} / \mathrm{dL}$ \\
\hline Urea & 200 & 286 & 248 & 192 & 95 & 42 & 61 & 41 & $17-43 \mathrm{mg} / \mathrm{dL}$ \\
\hline Cre & 11.71 & 15.06 & 11.81 & 8.12 & 3.07 & 1.74 & 1.91 & 1.03 & $0.7-1.3 \mathrm{mg} / \mathrm{dL}$ \\
\hline Uric acid & 13.87 & 12.69 & 9.42 & 9.08 & 5.22 & & 6.14 & 6.27 & $3.5-7.2 \mathrm{mg} / \mathrm{dL}$ \\
\hline Albumin & 36.2 & 25.6 & & 27.2 & 27.7 & 28.4 & 32.2 & 39.8 & $35-52 \mathrm{~g} / \mathrm{L}$ \\
\hline ALT & 65 & 43 & & & & & & & $0-50 \mathrm{U} / \mathrm{L}$ \\
\hline AST & 61 & 31 & & & & & & & $0-50 \mathrm{U} / \mathrm{L}$ \\
\hline LDH & 533 & 326 & & & & & & & $0-248 \mathrm{U} / \mathrm{L}$ \\
\hline GGT & 24 & 23 & & & & & & & $0-55 \mathrm{U} / \mathrm{L}$ \\
\hline ALP & 55 & 37 & & & & & & & $30-120 \mathrm{U} / \mathrm{L}$ \\
\hline Total bilirubin & 0.56 & 0.86 & & & & & & & $0.3-1.2 \mathrm{mg} / \mathrm{dL}$ \\
\hline Direct bilirubin & 0.14 & 0.32 & & & & & & & $0-0.2 \mathrm{mg} / \mathrm{dL}$ \\
\hline Indirect bilirubin & 0.42 & 0.54 & & & & & & & $0-0.7 \mathrm{mg} / \mathrm{dL}$ \\
\hline CK & 671 & 129 & & & & & & & 0-171 U/L \\
\hline $\mathrm{Na}$ & 129 & 134 & & & & & 140 & 141 & $136-146 \mathrm{mEq} / \mathrm{L}$ \\
\hline K & 5.3 & 4.7 & & & & & 5.3 & 5.1 & $3.5-5.1 \mathrm{mEq} / \mathrm{L}$ \\
\hline Cl & 87 & 93 & & & & & & & 101-109 mEq/L \\
\hline Ca & 8.4 & 7.2 & & & 5.9 & 6.3 & 8.6 & 9.6 & $8.8-10.6 \mathrm{mg} / \mathrm{dL}$ \\
\hline$P$ & 12.7 & 10.9 & & & & & & 3.9 & $2.5-4.5 \mathrm{mg} / \mathrm{dL}$ \\
\hline Mg & 2.9 & 2.7 & & & & 1.5 & & & $1.8-2.6 \mathrm{mg} / \mathrm{dL}$ \\
\hline CRP & 120.3 & 67.3 & 104 & & 84 & 38.8 & & 3.9 & $0-5 \mathrm{mg} / \mathrm{L}$ \\
\hline WBC & 8.57 & 8.04 & 13.4 & & 6.25 & & & & $4.5-10.5 \times 109 / \mathrm{L}$ \\
\hline HGB & 17.2 & 12.7 & 11.1 & & 10.3 & & & & $12-18 \mathrm{~g} / \mathrm{dL}$ \\
\hline Platelet & 386 & 230 & 359 & & 348 & & & & $130-400 \times 109 / L$ \\
\hline Lymphocyte & 0.61 & 0.77 & 1.38 & & 1.26 & & & & $1-4.8 \times 109 / \mathrm{L}$ \\
\hline Neutrophile & 7.64 & 6.47 & 10.69 & & 4.29 & & & & $1.8-8 \times 109 / \mathrm{L}$ \\
\hline Ferritin & 2319.9 & & 978.3 & & & & & & $18.5-306.5 \mathrm{ng} / \mathrm{mL}$ \\
\hline Troponin I & 0.030 & & 0.56 & & & & & & $0.02-0.06 \mathrm{ng} / \mathrm{mL}$ \\
\hline CK-MB & 14.94 & & & & & & & & $0-5 \mathrm{ng} / \mathrm{mL}$ \\
\hline PT & 41.7 & & 21.4 & & & & & & $12-17 \mathrm{sec}$ \\
\hline aPIT & 37.9 & & 39.7 & & & & & & $24.8-34.4 \mathrm{sec}$ \\
\hline INR & 3.35 & & 1.65 & & & & & & $0.8-1.3$ \\
\hline D-dimer & 4630 & & 1500 & & & & & & $80-654 \mu \mathrm{g} / \mathrm{L}$ \\
\hline PCT & 38.79 & & 1.18 & & & & & & $0-0.5 \mathrm{ng} / \mathrm{mL}$ \\
\hline Fibrinogen & 630 & & & & & & & & $200-400 \mathrm{mg} / \mathrm{dL}$ \\
\hline ESR & & 50 & & & & & & & $0-20 \mathrm{~mm} / \mathrm{h}$ \\
\hline pH & 7.19 & 7.18 & 7.01 & 7.104 & 7.09 & & & & $7.35-7.45$ \\
\hline pC02 & 37.5 & 31.6 & 38.7 & 52.1 & 60.1 & & & & $35-45 \mathrm{mmHg}$ \\
\hline HCO3 & 13.3 & 12.4 & 10.8 & 13.6 & 14.4 & & & & $22-26 \mathrm{mEq} / \mathrm{L}$ \\
\hline
\end{tabular}

*First day of hospitalization

Abbreviations: Cre, creatinine; ALT, alanine transaminase; AST, aspartate transaminase; LDH, lactate dehydrogenase; GGT, gamma-glutamyl transferase; ALP, alkaline phosphatase; CK, creatine kinase; Na, sodium; K; potassium; Cl, chloride; Ca, calcium; P, phosphor; Mg, magnesium; CRP, C-reactive protein; WBC, white blood cell; HGB, hemoglobin; CK-MB, creatine kinase-MB; PT, prothrombin time; aPTT, activated partial thromboplastin time; INR, international normalized ratio; PCT, procalcitonin; ESR, erythrocyte sedimentation rate; PCO2, partial pressure of $\mathrm{CO2}$; $\mathrm{HC} 03$, bicarbonate 


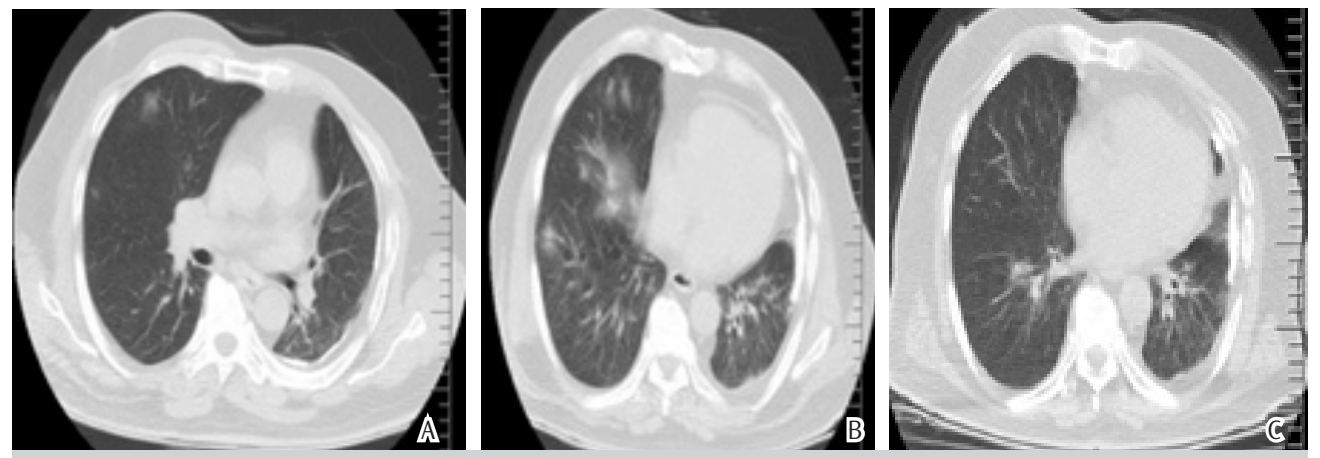

Figures (A-B-C), CT scans of the thorax demonstrate bilateral multiple ground-glass opacities, which are more remarkable on the right, and pleural effusion on the left. On the left, there is calcification and volume loss due to tuberculosis sequelae.

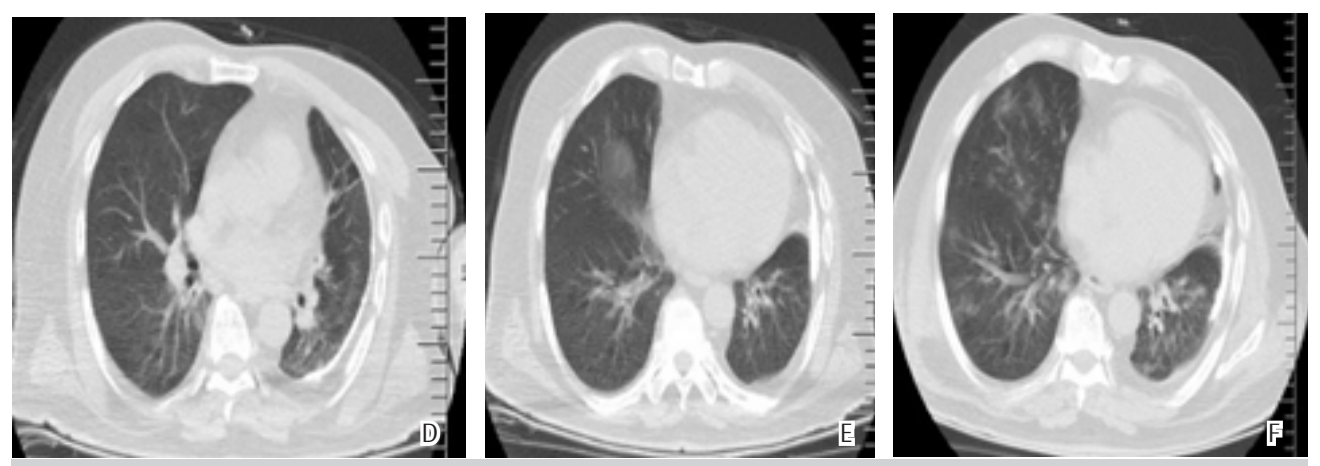

Figures (D-E-F), in the control thorax CT images, bilateral multiple ground-glass opacities disappeared. Relative pleural effusion was observed on the left lower side.

When he was admitted to the hospital, he had anuria, metabolic acidosis, hypotension and hypervolemia (pretibial edema and effusion in the lung). He had rhabdomyolysis findings (metabolic acidosis, hyperuricemia, hypocalcemia, hyperphosphatemia, creatine kinase and lactate dehydrogenase elevations). D-dimer, fibrinogen, prothrombin time, activated partial thromboplastin time and international normalized ratio (INR) elevations show that his coagulation cascade was affected negatively. He was initially followed up in the pandemic service. HD was administered to him for one session. His blood oxygen saturation (78\%) declined and his hypotension $(70 / 50 \mathrm{mmHg}$ ) occurred. When his hemodynamics was unstable, he was transferred to ICU. Inotropic support was provided to him. HD was administered to him for two sessions. Discharge of urine was ensured on day 10. Cre was on a declining trend on day 13. During outpatient follow-up, his thorax CT findings associated with COVID-19 improved within four and a half months.

T-cell immunity is recognized as a key factor to ensure recovery from SARS-CoV-2 infection (6). Uremia status is linked with extensive impairment of lymphocyte and granulocyte function. An abnormal immune system may alter the response to SARS-CoV infection (7). According to a retrospective study conducted on 333 patients that contracted COVID-19 pneumonia, the mortality rates of those patients that had kidney dysfunction were significantly higher than the patients that had no kidney involvement (11.2 and 1.2\%, respectively) (8). In a single-center, retrospective, observational study conducted on a group of 287 patients, 55 of these patients had manifestations of AKI as defined by the Kidney Disease Improving Global Outcomes (KDIGO). The age of these patients was significantly higher, and the majority of them was male, and had other comorbidities, including chronic renal insufficiency, HT and cerebrovascular disease. The severity of pneumonia tended to be significantly higher in these patients (not peer-reviewed) (9). To manage COVID-19 disease that is associated with AKI, supportive therapy has been used; however, nephrotoxic drugs have been avoided, and from the very beginning, renal replacement therapy has been used as much as possible (10). The potential effects of SARS-CoV-2 on the kidneys are still unknown. However, the evidence that has been collected so far demonstrates that kidney complications are frequent, and COVID-19 disease may have unique characteristics concerning those individuals that receive chronic dialysis treatment and the kidney transplant recipients (11). The impacts of COVID-19 on the long-term kidney function of patients are required to be more comprehensively studied.

This case is unique in certain negative conditions. Firstly, he was an old male individual. In certain studies, male sex has been suggested as a risk factor (12). According to the reports published so far, even if patients of all ages are sensitive towards the disease, individuals developing a critical illness 
are older and have a greater number of comorbid conditions (13), which suggest higher mortality rates and poor results in the patients that have comorbid conditions. Secondly, he had severe pneumonia due to his comorbidity condition (DM, $\mathrm{HT}$ ). There were sequelae of tuberculosis in his lung. At the same time, his left lung volume decreased due to tuberculosis. Although diabetic nephropathy is an important comorbid condition and AKI is recognized as one of the main risk factors for poor results during COVID-19 infection, the effects of the infection on other kidney diseases, for instance, on endstage renal disease, is still unknown (11). Thirdly, he had severe $\mathrm{AKI}$ and needed $\mathrm{HD}$. HD was administered in compliance with the isolation rules. Fourthly, our patient did not need high-flow rate oxygen (HFO), intubation and mechanical ventilation. During his follow-up, cardiopulmonary resuscitation (CPR) did not occur. Fifthly, while he received single oxygen (nasal) during his follow-up in the ward, he needed dual oxygen (nasal and oral) during his follow-up in the ICU. Sixthly, convalescent plasma and tocilizumab were not administered to him. Seventhly, his kidney functions normalized and the COVID-19 pneumonia findings in his lung improved.

\section{CONCLUSION}

We describe a patient with COVID-19 pneumonia in this case study. Previously, he did not have any additional diseases other than DM and HT. He had COVID-19 pneumonia accompanied by severe AKI. He needed HD for three sessions. He recovered and his kidney functions were restored. It is possible to treat COVID-19 pneumonia accompanied by AKI with close follow-up and controlled HD. In this patient group, on-time and on-site hemodialysis treatment can be lifesaving.

\section{ACKNOWLEDGEMENT}

Peer-Review

Externally Peer Reviewed

Conflict of Interest

The authors declare that they have no conflict of interests regarding content of this article.

Financial Support

The authors report no financial support regarding the content of this article.

Financial Support

No financial support was used by authors during this study.

Ethical Declaration

Informed consent was obtained from the participant and Helsinki Declaration rules were followed to conduct this study.

\section{REFERENCES}

1. Wu Z, McGoogan JM. Characteristics of and important lessons from the coronavirus disease 2019 (COVID-19) outbreak in China: summary of a report of 72314 cases from the Chinese Center for Disease Control and Prevention (published online ahead of print February 24, 2020). JAMA. https://doi. org/10.1001/jama.2020.2648.
2. US Renal Data System. https://www.usrds.org/Default.aspx Accessed March 3, 2020.

3. Durvasula R, Wellington T, McNamara E, et al. COVID-19 and kidney failure in the acute care setting: our experience from seattle. Am J Kidney Dis. 2020; 76:4-6. https://doi. org/10.1053/j.ajkd.2020.04.001.

4. Hirsch JS, Ng JH, Ross DW, et al. Acute kidney injury in patients hospitalized with COVID-19. Kidney Int. 2020; 98:209-18. https://doi.org/10.1016/j.kint.2020.05.006.

5. Chen N., Zhou M., Dong X. Epidemiological and clinical characteristics of 99 cases of 2019 novel coronavirus pneumonia in Wuhan, China: a descriptive study. Lancet. 2020; 395:507-513.

6. Liu W.J., Zhao M., Liu K. T-cell immunity of SARSCoV:implications for vaccine development against MERS-CoV. Antiviral Res. 2017; 137: 82-92.

7. Pesanti E.L. Immunologic defects and vaccination in patients with chronic renal failure. Infect Dis Clin North Am. 2001; 15: 813-832.

8. Pei G, Zhang Z, Peng J, et al. Renal involvement and early prognosis in patients with COVID-19 pneumonia. J Am Soc Nephrol. 2020; 31: 1157-65. https://doi.org/10.1681/ ASN.2020030276.

9. Xiao $\mathrm{G}, \mathrm{Hu} \mathrm{H}, \mathrm{Wu} F$, et al. Acute kidney injury in patients hospitalized with COVID-19 in Wuhan, China: a single-center retrospective observational study. medRxiv. (2020). https:// doi.org/10.1101/2020.04.06.20055194. (Epub ahead of print).

10. Cheng Y, Luo R, Wang K, et al. Kidney disease is associated with in-hospital death of patients with COVID-19. Kidney Int. 2020; 97: 829-38. https://doi.org/10.1016/j.kint.2020.03.005.

11. Perico L, Benigni A, Remuzzi G. Should COVID-19 concern nephrologists? why and to what extent? the emerging impasse of angiotensin blockade. Nephron. 2020; 144: 213-21. https:// doi.org/10.1159/000507305.

12. McMichael TM, Currie DW, Clark S, et al. Epidemiology of COVID-19 in a long-term care facility in King County, Washington. N Engl J Med. 2020; 382: 2005-11. https://doi. org/10.1056/NEJMoa2005412.

13. European Centre for Disease Prevention and Control Infection prevention and control for the care of patients with 2019$\mathrm{nCoV}$ in healthcare settings. https://www.ecdc.europa.eu/ en/publications-data/infection-prevention-and-control-carepatients-2019-ncov-healthcare-settings 